CHAPTER TEN

\title{
BETWEEN STORYTELLING AND PATRIOTIC SCRIPTURE. THE MEMORY BROKERS OF THE DUTCH REVOLT*
}

\author{
Erika Kuijpers
}

During the violent sack of the Brabant town of Tienen or Tirlemont in 1635, a maidservant of a burgher family who had fled the town was tied to a tree and raped by two Dutch soldiers from the army of Frederick Henry of Orange. The young woman cried so pitifully that the soldiers began to feel sorry for her, and, as a compensation for her loss of honour, both men proposed marriage; she just had to choose one of them. So the maid did. The maid and the soldiers congratulated each other with this happy ending and had a meal and drinks together. Moreover, she showed her future husband where her employers hid their silverware and subsequently ran away with him and the stolen treasure. The author who recorded this story concludes with the moral: never tell your servants where you hide your valuables. ${ }^{1}$

The author of this story was Johannes Jakinet alias Jean Jaquinet, an antiquarian or chronicler from Louvain, living in Tienen. He was about twenty years old when he witnessed the sack of Tienen by the Dutch and French armies in 1635. We know little about his identity, social status or office, but during his life he compiled a number of lengthy manuscripts on the history of the Netherlands and the Duchy of Brabant. ${ }^{2}$ He recorded personal memories and information from learned sources, pamphlets and popular books as well as tales and jokes he acquired from hearsay.

* Research for this article was funded by an NWO VICI grant for the research project Tales of the Revolt. Memory, oblivion and identity in the Low Countries, 1566-1700, and with support of the IAP project City and Society in the Low Countries, 1200-1850.

1 Royal Library Albert I Brussels, MS. 10245-6 'Chronijck van Nederlant (1523-1636)', ff. $195^{-195 v}$; The passage by Jakinet on the siege and plundering of Tienen in 1635 can also be read in transcription in: P. Kempeneers, 'Jan Jaquinet en de verwoesting van Tienen', Oost-Brabant. Heemkundig tijdschrift van het Hageland en omgeving 21 (1984), 16-29, there 26-27.

2 We know of two other manuscripts both in the Royal Library Albert I in Brussels: MS. 15938, Joannes Jakenet, 'Historie der Nederlanden onder de regering van Albertus en Isabella Philippus IV en Karel II. 1612 tot 1683, met bygevoegde portretten' and MS. 21769, Jan Jaquinet, 'Chronyke der Nederlanden (1500-1693)'. 
We do not know whether his texts circulated widely, but it is clear that he did his very best to entertain his intended audience. In the early modern period, history was meant to entertain as well as moralise: some stories were meant to amaze, others to horrify the reader. A good story articulated a clear message, a warning or a lesson, or if not, at least had to be funny.

For readers today, it is not completely clear what this particular story was meant to convey nor whether we are meant to believe it. We are amazed because this maid agrees to marry her rapist, but we cannot be sure that this would also have surprised a seventeenth-century audience. In any case that audience is likely to have been scandalised because the maid stole the family's silverware. The tale confirmed popular views on the proverbial untrustworthiness of housemaids. To us, the lack of reference to any source-had there been witnesses to the rape? - gives the impression that Jakinet merely recounted an urban legend. Yet he gave his story an air of historical realism by adding specific details about the protagonists. These were people that his local audience might have known about. He tells us that the maid was named Maria Iuliano, that she was a beautiful brunette, and that she was the daughter of the quarter master of the regiment of Ian de Velasco. Her employers, the owners of the house, were 'Ioncker' (Sir) Negrona and his wife 'Iouffrau' (Mistress) Backs who had fled with their children to Louvain. This family really existed. ${ }^{3} \mathrm{He}$ also notes that Maria should not bear all the blame because she should not have been left alone and she had fought to defend her virginity. Jakinet does not explicitly mention his source, but it is likely that he knew this story from hearsay. Orally transmitted anecdotes can be recognised by their funny or unexpected plots and by their normative message, for instance through recounting the consequences of a transgression of norms and values. Although they may refer to a narrative context or common history that is familiar to the audience, they usually lack external information such as details about time, place and people that do not matter to the plot. Narrative structuring is essentially a process that gives meaning to events by identifying their role in and contribution to an outcome. ${ }^{4}$ During the structuring of narratives in plots details are omitted; some

3 Paul Kempeneers located the house of the family Negrona where the event should have taken place. Paul Kempeneers, Thuis in Thienen (Tienen: Orientaliste, 1999), 357-359.

4 Donald E. Polkinghorne, 'Narrative psychology and historical consciousness. Relationships and perspectives', in Jürgen Straub (ed.), Narration, identity, and historical consciousness (Oxford and New York: Berghahn Books, 2005) 3-22, there $5^{-6 .}$ 
parts of the story will be condensed while others need to be sharpened or accentuated. Over time the storyteller will also get rid of inconsistencies and loose ends, while external, context-dependent information gets lost. ${ }^{5}$ Once younger generations start to write down the tales they have heard from their parents and grandparents, the lack of historical detail in oral accounts may become a problem.

Seventeenth-century histories were expected to contain some references, facts and figures in order to be received as truthful. There are many ways to solve that problem. The simplest and a very common one is for the author to acknowledge that this is a story that he or she got from hearsay. Seventeenth-century authors often state that they heard their stories from old people. This is a way to say that there might be some truth in the tale as these old people had witnessed the events themselves, but, at the same time, such a disclaimer prepares the audience for a specific genre of story. Like Jakinet, authors may also try to recontextualise the story by adding details like names, places, exact data, etc. Usually they would enrich the text with their own historical knowledge: they place the story in a broader historical context and connect it to a specific time and location. Yet, the internal 'smoothing' of the story-the 'flattening', stereotyping and rationalisation that has taken place during oral transmission-cannot be undone. That is why orally transmitted stories often remain recognisable to the attentive reader.

The extraordinary experience of war was a rich source of inspiration for storytellers, as several chapters in this volume illustrate. Families and local communities were the bearers of memories shaped in tales that could easily be transmitted from one generation to the next during long winter nights at the fire. Today as well as in the sixteenth and seventeenth centuries orally transmitted memories play a constituent role in identity formation of social groups. Recalling extraordinary war tales of suffering, victory, escape, salvation and heroism, and narrating them is a way of belonging and being part of the family's or community's history. Therefore people usually care about the stories' preservation and become worried if their bearers are getting old and dying off. The boom in memory studies of the past decades has shown that orally transmitted memory has a lifetime of up to three generations. At the moment when the communicative memory of the past threatens to come to an end because of the passing away of one's elders, the children or grandchildren start writing the tales

\footnotetext{
5 Ibid., 9 .
} 
down. In the scholarly terms developed by Aleida and Jan Assmann, this is the moment when communicative memory turns into cultural memory. ${ }^{6}$

The transformation of communicative memory into cultural memory can also be observed three generations after the Dutch Revolt. From about the 1640 , seventy to ninety years after the early violent phase of the Revolt in the 156 os and 1570 s, there was a rise in memory activity. In the Northern Netherlands the disappearance of the war generation coincided with the Peace of Westphalia that was celebrated fairly extensively. ${ }^{7}$ Yet the local memory that flourished around the mid-seventeenth century does not seem to be related to that event. Its focus is on the heroic exploits of locals. Between 1640 and 1660 we see a growing number of local histories of the Revolt, often written by occasional or second-rate authors, who include in their volumes previously unpublished stories that seem to derive from local oral tradition. Many of their prefaces state that the authors felt a need to write these histories down because they were at risk of being lost to oblivion. ${ }^{8}$

This chapter explores how the authors of such local histories tried to merge oral tradition with the 'patriotic scripture' that had emerged in the historical literature in the decades before. ${ }^{9}$ They seem to have functioned as brokers between overlapping yet distinctive mnemonic communities. The historical canons that had developed in both the Northern and Southern Netherlands offered a highly charged but also quite generic tale of collective suffering and struggle, which demonised the enemy and affirmed the unity and religious and/or moral superiority of the people in one's own camp. ${ }^{10}$ At first sight the local tales recorded after 1640 did not

6 Jan Assmann, 'Communicative and cultural memory', in Astrid Erll, Ansgar Nünning and Sara B. Young (eds.) Cultural memory studies. An international and interdisciplinary handbook (Berlin and New York: De Gruyter, 2008), 109-118; Aleida Assmann, Der lange Schatten der Vergangenheit. Erinnerungskultur und Geschichtspolitik (Munich: C.H. Beck, 2006), 28.

7 Simon Groenveld, T'is ghenoegh, oorloghsmannen. De Vrede van Munster: de afsluiting van de Tachtigjarige Oorlog (The Hague: Sdu Uitgevers, 1997); Mieke B. Smits-Veldt, 'De viering van de Vrede van Munster in Amsterdam. De dichters Geeraardt Brandt en Jan Vos bevestigen hun maatschappelijke positie', De Zeventiende Eeuw 13 (1997), 193-200.

8 See for example: Arnoldus van Duin, Oudewaters moord. Of waerachtig verhael van d'oudheid, belegering, in-nemen en verwoesten der geseide stad. (Oudewater, 1669), f.A1.

9 The term patriotic scripture was coined by Simon Schama, The embarrassment of riches. An interpretation of Dutch culture in the golden age (London: Collins, 1987), Chpt. 2.

10 Jasper van der Steen, 'Goed en fout in de Nederlandse Opstand', Holland: regionaalhistorisch tijdschrift 43 (2011), 82-97; Judith Pollmann, 'No Man's Land. Reinventing Netherlandish Identities, 1585-1621', in Robert Stein and Judith Pollmann (eds.), Networks, regions and nations. Shaping identities in the Low Countries, 1300-1650 (Leiden: Brill, 2010), 241-262; 
meet the moral standards laid down by those patriotic scripts. They did not mention suffering or the ideals of freedom or the true religion as a motivation for the deeds of local heroes. The first section of this chapter summarises the problematic development of public memory after a civil war and the rise of canonic scripts in both the Northern and Southern Netherlands. The second section discusses two narratives of local heroism in the Northern Netherlands, while the third deals with an example from the region of Douai in the Southern Netherlands.

\section{Contested Memories of a Civil War}

In 1566, the seventeen provinces of the Low Countries, ruled by the Habsburg King of Spain, Philip II, became involved in a civil war that officially ended with the recognition of two separate states in 1648: the Dutch Republic in the North and the Habsburg Netherlands (more or less equivalent to today's Belgium) in the South. The persecution of Protestants combined with the centralizing policies of the regime had triggered a rebellion among a part of the nobility, nicknamed Gueux or 'Beggars', who were supported by a growing number of towns. In 1572, the Habsburg governor-general, the duke of Alba, began a violent military campaign to force the rebel cities to surrender. If they did not open their gates to the Spanish troops instantly, they were put to the sack. To punish the rebels Alba's soldiers were given free rein to plunder, and hundreds-sometimes thousands - of men, women and children were murdered or died trying to escape. The memory of these episodes could be contested. In most towns that joined the rebellion in 1572, the citizens had been intensely divided, between Protestantism and the old faith and between loyalty to the king and loyalty to the rebel leader William of Orange. Often, groups among the civic militia had opened the gates to the rebels against the will of a part of the ruling elites and the population. In some places religious strife had led to violence within the urban community. Between 1578 and 1584 religious polarisation in a number of Brabant and Flemish towns, including Ghent, Bruges, Malines and Antwerp, led to the emergence of Calvinist theocracies (the so-called Calvinist Republics), in which the Catholic

Judith Pollmann, “"Brabanters do fairly resemble Spaniards after all”. Memory, propaganda and identity in the Twelve Years' Truce', in Judith Pollmann and Andrew Spicer (eds.), Public opinion and changing identities in the early modern Netherlands. Essays in Honour of Alastair Duke (Leiden: Brill, 2007), 211-228. 
clergy and sometimes also lay citizens were harassed or expelled. ${ }^{11}$ In a place like Den Bosch, by contrast, Protestants were chased out of town by the Catholic civic militia in $1579 .^{12}$ In towns like Leiden and Haarlem, besieged by the Spanish army for months, the population suffered from food and fuel shortages and an outbreak of pestilence as well the continuous stress of threats of attacks. Other places had to bear the costs of garrisoning the troops of one side or the other. In the countryside, life was particularly unsafe. The population had to deal with both rebel and Spanish troops, who exhausted resources where they did not simply pillage and completely burn down the villages. ${ }^{13}$

Newsprints, pamphlets and songbooks about the conflict circulated widely from early on. Local histories had begun to appear very soon in larger towns, and from around 1600 the first 'national' histories of the conflict were also being published. ${ }^{14}$ Eventually smaller towns also got their histories. Most of these texts focused on political and military history. Local events like the sieges of Leiden, Haarlem and Alkmaar were also commemorated in annual ceremonies, sermons, plays, monuments, and art works in public. ${ }^{15}$ The commemoration of the war as a Netherlandish conflict was boosted in the years between 1600 and 1620 when debates about the continuation of the war and the relation between state and

11 Guido Marnef, Het Calvinistisch bewind te Mechelen, 1580-1585 (Kortrijk-Heule: UGA, 1987); G. Marnef, 'Brabants calvinisme in opmars. De weg naar de calvinistische republieken te Antwerpen, Brussel en Mechelen, 1577-1580', Bijdragen tot de geschiedenis 70 (1987), 7-21; Johan Decavele (ed.), Het eind van een rebelse droom. Opstellen over het calvinistisch bewind te Gent (1577-1584) en de terugkeer van de stad onder de gehoorzaamheid van de koning van Spanje (17 september 1584) (Ghent: Stadsbestuur Gent, 1984); Judith Pollmann, Catholic identity and the Revolt of the Netherlands, 1520-1635 (Oxford: Oxford University Press, 2011), 113-124.

12 Jozef A.M. Hoekx, Vruchten van de goede en de slechte boom. Heyman Voicht van Oudheusden over de godsdiensttwisten in zijn stad 's-Hertogenbosch en in Breda (1577-1581) (Den Dungen: Tilia Levis, 2008).

13 Leo Adriaenssen, Staatsvormend geweld. Overleven aan de frontlinies in de meierij van Den Bosch, 1572-1629 (Tilburg: Stichting Zuidelijk Historisch Contact, 2007).

14 The first histories of the Revolt in the Netherlands appeared in the late sixteenth century: Pieter Bor, Oorspronck, begin ende aenvang der Nederlantscher oorlogen, beroerten ende borgerlijcke oneenicheyden.... (Utrecht, 1595); Emanuel van Meteren, Belgische ofte Nederlantsche historie, van onsen tijden.: Inhoudende hoe de Nederlanden aenden anderen ghehecht, ende aen Spaengien ghecomenzijn ... Meest onder de regeeringhe van Philippus de II. coninc van Spaengien, tot synen doot, ende den vvtgaenden iare 1598. (Delft, 1599); Bernardino Mendoça, Commentaires mémorables des guerres de Flandres et Pays Bas depuis l'an 1567 jusques à l'an 1577: avec une sommaire déscription des pays bas (Paris, 1591).

15 Judith Pollmann, Herdenken, herinneren, vergeten. Het beleg en ontzet van Leiden in de Gouden Eeuw (Leiden: Primavera Pers, 2008); Judith Pollmann, Het oorlogsverleden van de Gouden Eeuw (Leiden: Universiteit Leiden, 2007). 
church had created a canonic popular patriotic narrative of the Revolt. ${ }^{16}$ Many publications in this period served as war propaganda. The party that opposed a peace with Spain tried to unify the population and bolster its arguments by stressing the collective experience of suffering, struggle and victory in the name of freedom. The Black Legend about Spanish tyranny proved an effective instrument in their war propaganda. ${ }^{17}$ An important element in this narrative was the innocence of the victims versus the 'barbarian cruelty' of the Spanish perpetrators. The anonymous victims were always depicted as harmless and defenseless: virgins, children, old people, pregnant women, and unborn babies. Some pictures referred to the biblical massacre of the innocents. The hanging of a pregnant woman in her doorway became an iconic theme in the history of the Dutch Revolt. ${ }^{18}$

Conditions for public memory practices were very different in the Southern Netherlands, parts of which 'reconciled' voluntarily with their Habsburg rulers, while others were reconciled by force. By 1585 , when the city of Antwerp fell to Alexander Farnese, all Calvinist bulwarks in the South had been captured by the Habsburgs and thousands of families of reformed citizens and sympathisers left for the North. While the Calvinist exiles in the North developed a narrative that recalled the example of the Israelites and their flight to Egypt, those who stayed home and reconciled with the regime and the Roman Catholic Church had to keep their memories private. ${ }^{19}$ All treaties by which provinces and cities were 'reconciled' with the King contained an article in which it was agreed that the past would be forgotten, an act of oblivion which was effectively a full

16 Carolina Lenarduzzi, “De oude geusen teghen de nieuwe geusen”. De dynamiek van het oorlogsverleden ten tijde van het Twaalfarig Bestand' Holland: regionaal-historisch tijdschrift 43 (2011), 65-81. See also chapter 2 by Jasper van der Steen in this volume.

17 Wolfgang Cilleßen, 'Massaker in Der Niederländischen Erinnerungskultur. Die Bildwerdung Der Schwarzen Legende', in Christine Vogel (ed.) Bilder des Schreckens. Die mediale Inszenierung von Massakern seit dem 16. Jahrhundert (Frankfurt am Main: Campus, 20o6), 93-135; K.W. Swart, 'The Black Legend during the Eighty Years War', in J.S. Bromley and E.H. Kossmann (eds.) Britain and the Netherlands (The Hague, 1975). Also very influential was a history book for children: Willem Baudartius, Spieghel der ievcht, ofte corte Cronijcke der Nederlantsche geschiedenissen: In de welcke...verhaelt...worden, de voornaaemste Tyrannien ende... wreedtheden, die door het beleydt der Coningen van Hispaengien... in Nederlandt bedreven zijn ... (Amsterdam, 1615).

18 Erika Kuijpers, 'The creation and development of social memories of traumatic Events. The Oudewater massacre of 1575', in Michael Linden and Krzysztof Rutkowski (eds.) Hurting memories and beneficial forgetting. Posttraumatic stress disorders, biographical developments, and social conflicts (London: Elsevier, 2013), 191-201.

19 See chapter 15 by Johannes Mueller in this volume. 
amnesty. ${ }^{20}$ This obligation to forget may also have stopped former Protestants or sympathisers in rebel towns like Bruges, Ypres, Ghent or Valenciennes from talking about their past. We have not found many manuscripts from this group that reveal their former sympathies. The absence of memory practices in the public sphere must have marked the identity of the former Protestant generation who remained in the South. Yet many in the population in fact welcomed the return of their legitimate overlord in the hope that the troubles would come to an end for good and that the Catholic religion would be protected. This is at least the sentiment that was expressed in many chronicles at the time. ${ }^{21}$ Soon, authors of local and regional histories and chronicles, many of whom belonged to the Catholic clergy, remembered the 'troubles' as a short and regrettable interruption of a continuous history of loyalty and piety: a test, as it were, of the true believers. Fortunately, with the help of the Virgin Mary and God, the heretics had been chased away and society was cured of its evils. Many of these accounts stress continuity. By contrast, we know very little about the social memory of the local populations. Still many people must have had memories that sat uncomfortably with this Counter-Reformation narrative of their past. Moreover, the works of local historians and antiquarians usually remained unpublished, like the collections of Jakinet. Their contents, however, give the impression that they functioned just as they did in the Dutch Republic, as brokers between popular memories, oral tradition and a canonic version of the past that focused on church and state as the best guarantors of religious orthodoxy. ${ }^{22}$

\section{Freebooters in the Reed. The Northern Netherlands}

In the local oral tradition in the North, narratives tended to be either miraculous or entertaining. There was something very spectacular about the success of the Revolt in the northern province of Holland. The first years of civic resistance and the guerilla tactics of the rebels, in particular, captured the imagination. Many successes were the fruit of cunning schemes and tricks. There are tales of attacks on Spanish troops by soldiers

20 Violet Soen, 'Reconquista and reconciliation in the Dutch Revolt. The Campaign of Governor-general Alexander Farnese (1578-1592)', Journal of Early Modern History 16 (2012), 1-22; Pollmann, Catholic identity, 126.

21 Pollmann, Catholic identity, 140-142.

22 Ibid., 165-173. 
hidden in peat barges and beer barrels or disguised as farmers' wives. ${ }^{23} \mathrm{~A}$ very prominent role in many stories is assigned to the watery landscape that was used by the Hollanders to their advantage. While the very wet soil posed a major logistic problem for the Spanish troops with their heavy cannon, the locals could swim and were agile with boats and on skates. They crossed fields intersected by ditches and canals by jumping across them with poles. Thus the rebels could escape from the Spaniards by hiding in the fringes of reed, luring the enemy into ambushes, getting away much faster or smuggling messages hidden in a pole between the besieged towns and the rebel forces. Indeed the first rebel successes-the Beggar's invasion in Den Briel in 1572, the relief of Alkmaar in 1573 and of Leiden in 1574-were achieved through the inundation of the countryside.

Many families were proud of the wartime past of their grandfathers and -mothers. A heroic or celebrated ancestor could add lustre to the reputation of the entire family. There are numerous examples of elite families especially, who successfully promoted their ancestors' illustrious deeds. A good example is the story of Jan Pieterszoon van der Lee from the Holland town of Oudewater. Oudewater was captured, sacked and burnt down by the Spanish army in 1575. Around 1660, when Arnout or Arnoldus van Duin, a local grocer, started to write a history of this event, he relied on what he had heard 'from old people who heard these stories many times from their ancestors' and 'from people whom I have known and whom I have spoken with myself, who have a good knowledge of the events and who were already seventeen years old at the time'. ${ }^{24}$ Some of his sources had told him their family stories. One of them must have been a relative of Jan Pietersz. van der Lee $\left(1545^{-1613}\right)$ who as a young man had joined the Beggar army at sea in 1572 . He was an excellent warrior, Van Duin writes, and there were so many stories about him that it would be impossible tell them all. ${ }^{25}$ Van der Lee was born into a leading family of rope-makers (Oudewater was known for the cultivation of hemp and the rope-making industry). Jan was elected alderman and was a captain of the civic militia. ${ }^{26}$

23 Many of these popular heroic stories were collected and published by a relatively unknown author named Petrus de Lange, Batavise Romeyn: ofte Alle de voornaemste heldendaden, ridderlijke feyten en listige oorlogs-vonden, in veld en zeeslagen, overwinninge van steden en schepen, en in andere gelegentheden, by de Hollanders en Zeeuwen verricht, zedert 1492 tot 1661 (Amsterdam, 1661).

24 Van Duin, Oudewaters moord, 32.

25 Ibid., 29.

26 Nettie Stoppelenburg, De Oudewaterse moord (Oudewater: Stichting Cultureel Sociaal Fonds Mooyman-Martens, 2005), 28-29. 
During the siege of Oudewater in 1575 he played an important role in the defence of the town. However, the defenders had to yield to superior numbers, and the rebellious town was sacked and many inhabitants killed as punishment. Jan Pieterszoon Van der Lee suffered a leg wound and was caught, but after he promised to pay a ransom, his life was spared. In the Spanish camp he found his good old friend Leendert Ariensz. van Dam among the other prisoners. After Van Dam convinced the Spanish soldiers that someone in a nearby town owed him a large sum, they gave him three days to collect the money, meanwhile holding Van der Lee as a hostage. Yet Van der Lee urged Van Dam not to return. He then persuaded the Spaniards that two thousand guilders were buried in the yard of the house of his uncle. When two soldiers accompanied him to his uncle's house he pretended to be so severely wounded that he could hardly walk. At the house one of the soldiers went looking for a spade, and Van der Lee knocked down the other and escaped over a fence.

Van Duin does not spare his readers the gory details. During Van der Lee's flight, the flesh was hanging loose from his injured foot so he cut off the flapping tissue himself. Once, in accordance with their plan, he was reunited with his friend Van Dam in a neighbouring town, the two men, now penniless, decided to earn their living as porters in the town of Gouda. During this period the countryside around Gouda was particularly unsafe because of the deserters from the Spanish forces prowling around. The town of Gouda put up a prize of fifty guilders for each soldier taken prisoner and brought to town. Van der Lee killed one in ambush and cut off the poor man's head. 'Yet, because the head was bald, and he could not carry it by its hair, he had to take it to town with his fingers in the mouth to the great amazement of the people who saw him pass by'. In 1578, Van der Lee returned to Oudewater and took up his old craft of rope-making again. He was again chosen alderman and later was elected burgomaster. At the time of his death in 1613 he was a well-to-do man of distinction.

For the Van der Lee family this tale must have been a satisfactory narrative. Their grandfather had been fearless, clever and persistent. Through his hard work the family's rope yard became a flourishing enterprise that still exists today. ${ }^{27}$ The story was exciting, spectacular and funny, as well as a little gruesome. Yet, these elements were not sufficient to secure Van der Lee a place as a national hero in the historiography of the Revolt in

27 http://www.touwfabriekvanderlee.nl/touwfabriek/historie, consulted on 15 February 2013 . 
subsequent ages. Perhaps the family could have done more to spread the fame of their forefather. The case of a famous burgomaster of Leiden shows that good stories about individual heroism could develop retrospectively. Burgomaster Van der Werf's heroic offer of his own flesh to the starving population of Leiden was probably invented well after the siege had been lifted but that did not stop it from becoming one of the most famous stories in the history of the Revolt. ${ }^{28}$ The tale of Van der Lee contains no mention of self-sacrifice and no clear signs of piety or godliness. In the book by Van Duin, however, the context of the suffering of the Oudewater population helps to turn Van der Lee into an exemplary patriot nevertheless.

Oral traditions of the Revolt did not always match the moral standards of the narrative templates of suffering and courageous self-sacrifice for freedom, religion or fatherland. In an area north of Amsterdam, called Waterland, local farmers and freebooters in the 1570 s attacked Spanish convoys on both land and water in order to claim the material proceeds that helped their families to survive and the rebels to continue the military resistance. The royal army had great difficulties getting this area under control. It was of strategic importance as it bordered the waterway between Amsterdam, loyal to the king, and Haarlem, a rebel city that was besieged in 1573. The guerrilla war waged in this region generated many popular stories. Just as in Oudewater, however, it took a long time before a local historian began to write them down. Hendrik Jacobszoon Soeteboom, alias Soet, born in 1615, was the son of an innkeeper in Zaandam, a small town north of Amsterdam. Here he went to school, managed to learn Latin, and opened a bookshop. From 1640 onwards he started to publish works on the local history and archaeology of the area around Zaandam and Waterland. ${ }^{29}$ In his Zaanlandze Arcadia, first published in

${ }^{28}$ Jori Zijlmans, 'Pieter Adriaensz. van der Werf. Held van Leiden', in Joris van Eijnatten, Fred van Lieburg and Hans de Waardt (eds.), Heiligen of helden. Opstellen voor Willem Frijhoff (Amsterdam: Bert Bakker, 2007), 130-143.

29 Soeteboom was very productive and wrote a number of regional histories as well as theatre plays. For example: Hendrik Soeteboom, Vroonens begin, midden en eynde, met het opkomen der steden van West-Vrieslant, waer in nevens andere dingen te vinden is de alder oudtste en voornaemste geschiedenissen van West-Vrieslant tot aen de val van hare oude hooftstadt Vroonen, met het opkomen der steden Hoorn, Enckhuysen, Alckmaer en Medenblick, en de bloedige oorlogen, tusschen de Hollanders en kleyne Vriesen, tot het jaer 1303, alles in 4. boecken (met vlijt) by een vergadert en met kopere platen verciert (Amsterdam, 1661); Hendrik Jacobsz Soeteboom, De historie van Waterland: behelsende de oude, besondere en ghedenckwaerdige geschiedenisse van Waterlandt en de Waterlanders: mitgaders de steden van Edam, Munckendam, en de alle dorpen van Waterlandt: als mede een breede en generale 
1650, he also wrote about the impact of the war in this area in the years $1572-1578.30$

The book is a curious mixture of poorly matched ingredients. Just like Van Duin in Oudewater, Soeteboom had clearly read and used the work of several well-known historians of the Revolt, including local histories of nearby Haarlem and Hoorn. Furthermore he reported on his findings in the archives of the local magistrates, where he retraced political decisions as well as the financial administration of the payments for garrisons and labour for defence works for instance, uncovering a war economy in detail. But a large part of his narrative consists of stories which older people had told him. His own grandfather seems to have been one of his sources. ${ }^{31}$ That his sources were local can be surmised from the fact that so many people and locations are precisely named.

Here is a typical story about the activities of the freebooters which Soeteboom heard from an old farmer who was working on the land near Amsterdam. During the siege of Haarlem a number of Spanish soldiers sailed from Amsterdam to the Spanish camp outside Haarlem. When the Spaniards came ashore for a break, as the weather was nice, the freebooters emerged from their hiding places and killed them all. They cut off the noses and ears and pinned them on their hats.

On another occasion, when the freebooters in Waterland had run out of money after having been drinking at an inn, they headed for the village of Assendelft, still in the hands of the royal troops. There they went to the house of a rich single woman, whom they lifted from her bed and carried off into their boat in order to force her to pay a ransom for her freedom. On the way her nightgown was torn from top to bottom. She cried and screamed, complaining that they did not want her for her body but just for the money. One of the men piously covered her with his own cloak. There were many accounts like this, funny as well as wondrous, and some cruel. Soeteboom mentioned one occasion where the freebooters cut off the private parts of the enemy captain they killed and brought them home as a trophy. He added that he was ashamed to tell this story, yet apparently these actions were understandable and acceptable in the extreme context of warfare and perhaps also excused by existing template of Spanish inhuman cruelty and oppression. Soeteboom's book and the

beschrijvinge van 't begin, opgangh en voortgangh der stadt en heerlijckheyt van Purmer-endt (Amsterdam, 1660).

${ }^{30}$ Hendrik Jacobsz. Soeteboom, Zaanlandze arcadia in vyf boeken verdeelt (s.l., 1650).

31 Ibid., $45^{2}$. 
tales that he told have subsequently been forgotten. Only one Waterland hero entered the national history books, although the origin of this story is a mystery according to historians who have tried to identify the protagonist. ${ }^{32}$ This is a story that qualifies as a moral lesson. ${ }^{33}$ When the royal troops were approaching the village of Westzaan, a young peasant left his belongings behind and put his old mother on a sledge and brought her all the way over the ice from Waterland to the town of Hoorn. In Hoorn the magistrates commemorated this event by commissioning a wooden sculpture above one of the town gates with the following text:

When the state and Westzaan sighed under tyranny

This brave son saved his mother from death

And flew to this place in this manner

Thus a noble child shows his loyalty to his parents in times of need ${ }^{34}$

\section{Heretics in the Woods: Southern Netherlands}

In the very south of the Netherlands, in the area between Lille, Tournai, Valenciennes and Douai, Calvinist preachers attracted huge crowds in the summer of 1566, and many 'petites nobles' here were among the supporters of the new faith. ${ }^{35}$ After a wave of iconoclasm erupted in August in Steenvoorde, the violence spread rapidly to the east as well. The Catholic bulwarks of Lille and Douai were saved, yet Tournai and Valenciennes and many other towns in the area were heavily damaged by the imagebreakers. The government of Valenciennes, the 'new Geneva', was practically taken over by the Calvinist consistory in the autumn of 1566 , but it was reconquered and punished by Philip of St. Aldegonde, the baron of Noircarmes a few months later. ${ }^{36}$ The area remained in turmoil until peace and order were restored by the end of the 1570s. In many towns

32 G.J. Honig, 'Lambert Melisz. van Westzaan en zijn nageslacht te Hoorn', De Zaende. Maandblad gewijd aan de historie, folklore en genealogie van de Zaanstreek (1948), 324-334; Simon Hart, 'Lambert Melisz. De huisman van Westzaan?', West-Friesland's 'oud en nieuw' 24 (1957), 54-59.

33 Soeteboom himself devoted a play to this theme: Hendrik Jacobsz Soet, Batavische Eneas, of getrouheyts voor-beelt, nevens de verwoestinge van West-Zanen ende Crommenije, geschiet anno 1574. Treur-spel (Alkmaar, 1645).

34 Simon Hart, 'Lambert Melisz.', 54.

35 Alain Lottin and Philippe Guignet, Histoire des provinces Françaises du Nord. De Charles Quint à la Révolution française (1500-1789) (Arras: Artois Presses Université, 2006), 73-80.

36 Ibid., 87-9o. 


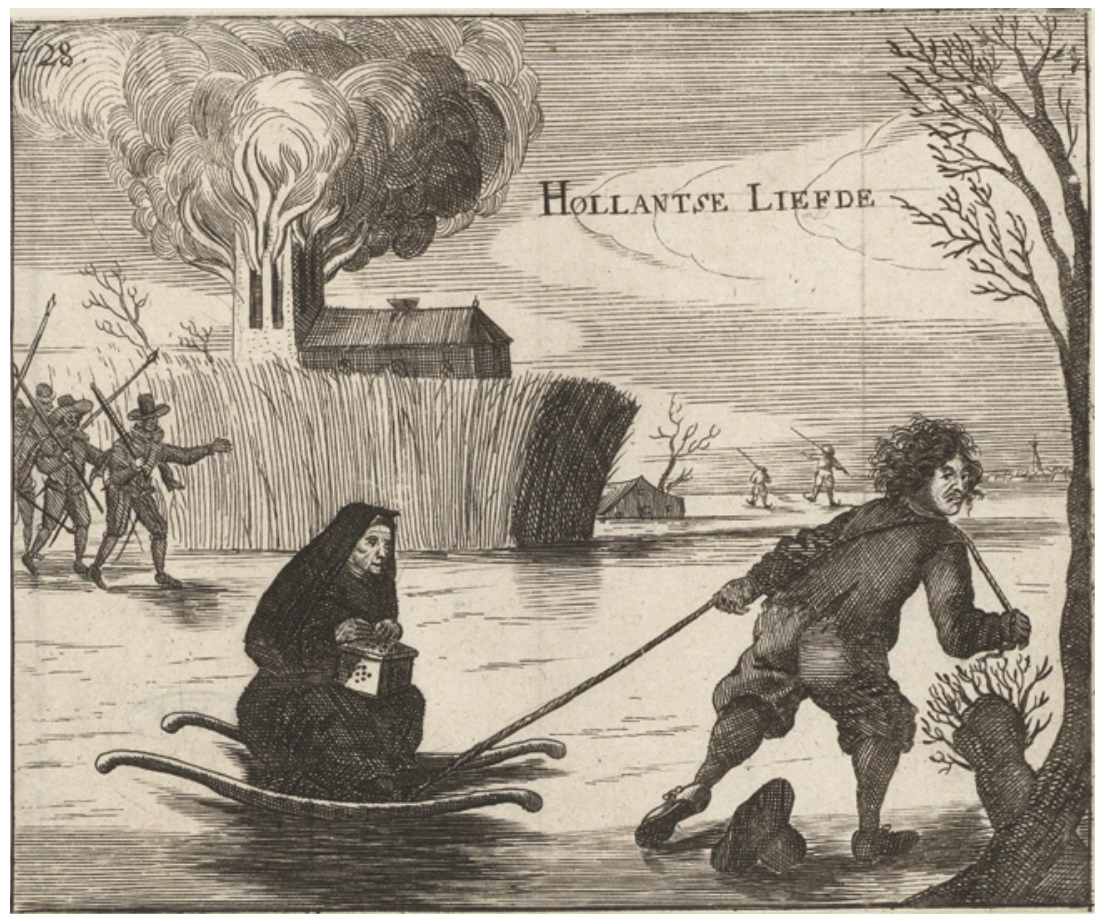

Fig. 10. Lambert Melisz saves his mother from plundering soldiers. Anonymous print 1659-1661, Rijksmuseum Amsterdam.

in this region chroniclers wrote of the history of the troubles as a closed chapter. Few of those works were published at the time; one exception is the history of Tournai published by canon Jean Cousin $(† 1636)$ in 1619. In this voluminous work a thousand years of history since the first Christians and early medieval times serve to demonstrate the venerable antiquity and authority of the Catholic Church in Tournai as well as its constancy in times of troubles over the centuries. The second volume bears a dedication to Charles de Lalaing, the count of Hoogstraten, in which the author expresses his hope that the last Calvinists in Tournai would be convinced by this long history of miracles and devotion, all the more so because heretics could not boast any miracles of their own. ${ }^{37}$

37 Jean Cousin, Histoire de Tournay, ou Quatre livres des chroniques annales, ou demonstrations du christianisme de l'évesché de Tournay... (Douai, 1619); There is also a later edition of the works edited by the Société Historique et Littéraire de Tournai: Jean Cousin, Histoire de Tournay, (Tournai: Malo et Levasseur, 1868) vol. II. 
In the last chapters Cousin finally treats the troubles of 1566 . There he mentions the fact that many farmers in and around Douai remained des bonnes catholiques thanks to a course of events which had unfolded on the morning of 26 August. After iconoclasts had pillaged the churches of Marchennes, farmers directed by one Fery de Guyon (1507-1567), the bailiff of Anchin, hunted down a group of 'heretics' in the woods and 'cut them into pieces'. The following day fights were again reported during which many Calvinists were killed. ${ }^{38}$

Fery de Guyon had been a soldier who spent a long career in the service of Charles V. He had served in the Italian wars, was present at the sack of Rome in 1527 and was later promoted to the archers du corps of the king. He became bailiff of Anchin shortly after the Peace of Cateau-Cambrésis in 1559. At some point he had married a girl from Tournai, Jeanne de Saint Raagon, and had returned to the region every now and then, having nine children with her. When he settled down for good in the town of Pecquencourt near Douai, he started to write his memoirs, a cheerful tale of many adventures. Just as in many other contemporary soldier memoirs he mainly reports on the military aspects of war and very little on his personal experiences. Expressions of emotions and piety are rare. ${ }^{39}$ Here is his account of the events of August 1566: On Sunday 25 August about four or five hundred men ransacked the church of Marchiennes as well as, 'unreasonably, the houses of monsieur Buret et monsieur Magaret'. That evening De Guyon met the prelat of the Abbey of Anchin in the town of Pecquencourt, who was on his way to seek refuge in Douai because he feared that the vandals would soon visit Anchin, 'if God would not intervene'. 'I answered laughing that our sins were the cause'. ${ }^{40}$

De Guyon returned to his home in Pecquencourt, where he found the assembled community on the market place in an agitated mood. But De Guyon 'answered them smiling (tout en riant) that God would give a remedy'. ${ }^{41}$ Then De Guyon mounted his horse again and visited several villages in the neighbourhood and mobilised a good number of peas-

38 Cousin, Histoire de Tournay, vols. 3-4 (Tournai: Malo et Levasseur, 1868), 316.

39 For the differences in the representation of individual experience in pre-modern and modern memoirs see the work of Yuval Noah Harari, Renaissance military memoirs. War, history, and identity, 1450-1600 (Woodbridge: Boydell Press, 2004); Yuval Noah Harari, 'Martial illusions. War and disillusionment in twentieth-century and renaissance military memoirs', Journal of Military History 69 (2005), 43-72.

40 Fery de Guyon, Mémoires de Fery de Guyon, ecuyer, bailly général d'Anchin et de Pesquencourt, ed. A.P.L. de Robaulx de Soumoy (Brussels: Heussner, 1858), 145-150.

41 Ibid., 146. 
ants who promised to come to his assistance at the ringing of the big bell of Pecquencourt. The next morning, before dawn, the bell rang, and with about 700 men and 24 horses they marched in the direction of Marchennes. They took Marchennes and chased the heretics out of town. And although De Guyon subsequently gave a sign to retreat, afraid that the rebels would ambush his men in the woods, many men pursued the Calvinists nevertheless. In total they killed about 70 or 80 of them. Back in Anchin, they were treated to a rich meal with beer, cheese and bread. Yet in the afternoon a preacher with 400-500 followers had again returned to Marchennes, and now the whole population was up in arms. Again the bells rang and the men chased the Calvinists in the direction of Brillon. There, they encountered the seigneur of the neighbouring village of Warling and his company, who again killed many 'sectarians', almost as many as had been killed in the morning. "This was the first defeat of the sectarians, we pray that the Almighty is contented, we have done this in the service of the king and the commonwealth', De Guyon concludes. ${ }^{42}$ In the next chapter he describes how he was rewarded for these exploits with a horse from the stables of Margaret of Parma and a sum of 50 écus.

The memoirs of Fery de Guyon were published in 1664 by his grandson Pierre de Cambry, who was a canon in Tournai. ${ }^{43}$ The publication is dedicated to Count Philip of Egmont. The central motive for publication according to the dedication was to make known the exploits of this old soldier in the summer of 1566 . The grandson apologises for the patois used in the memoirs, as they were written by a humble servant of the king, but considering 'his zeal to the extinction of the infidels and other enemies to the Catholic faith', De Cambry is confident that the reader will forgive De Guyon his naivety. By way of extra proof of the truth of this story he has added at the end of the book a song (chanson de joye) that the farmers in and around Pecquencourt 'passed on from father to son and are still singing today as they learned it from their ancestors' ${ }^{44}$ Pierre de Cambry believed that the deeds of his grandfather had brought blessings upon the family as a whole. At the end of the memoirs he added some genealogical details of the family and especially of the life of his eldest sister, Jenne

42 Ibid., 150.

43 Fery de Guyon, Les mémoires non encor veues du sieur Fery de Guyon... contenant les batailles, sièges de villes, rencontres, escarmouces, où il s'est trouvé, tant en Afrique, qu'en Europe pour l'empereur Charles V\& Philippe II roy d'espagne, son fils de glorieuse mémoire, ed. P. de Cambry (Tournai, 1664).

44 Ibid., f. A3v; see also the appendix at the end of this chapter. 
de Cambry, who was an Augustinian nun in Tournay and Lille where she died in an air of sanctity in 1639 at the age of 58 :

To whom our good God bestowed so many graces and heavenly favours that one may piously believe that this has been in reward of the services which her grandfather rendered to the Catholic faith by his arms and honour, which was also noted by lord provost Mr. André Catullus and Mr. Jacques Groulard the treasurer, canons of the collegiate church of Renaix, as censors in their approbation of these memoirs by Mr. De Guyon, who is now with God. ${ }^{45}$

\section{Conclusion}

The local memory of the glorious deeds of Fery de Guyon fitted beautifully with the Counter-Reformation rhetoric of the works of authors like Cousin. He represented an ideal of militant Catholics who risked their lives to destroy heretics. Although De Guyon himself in his memoirs focuses on the material rewards his adventures brought him, his grandson apologised for the 'naivety' of the narrative and stressed the godliness of De Guyon's deeds and the eternal rewards for his descendants. Apparently it was not so difficult to connect the 1566 killings of Calvinists with a long history of Catholic zeal.

The extraordinary exploits of the war generation were deployed to embellish the war record of families in the Northern Netherlands as well. In the oral tradition a connection with a grand narrative of patriotic struggle for freedom or a true faith may not have been explicit, but local authors could still present these stories within that context. In a recent article on the lifecycle of myths, Judith Pollmann argues that stories from oral tradition would continue to thrive 'only when they were framed historically and/or supported by material evidence'. She demonstrates that historians and antiquarians are usually the main providers of that evidence. ${ }^{46}$ And indeed, Jakinet gives us the names of the maidservant who was raped, as well as the name of her master, while Pierre de Cambry offers evidence for the significance of the acts of De Guyon by adding a variety of details: the song 'that is still sung to date', the story of the saintly life of his sister, and the authority of the censors. Arnoldus van Duin and Hendrik Soeteboom

\footnotetext{
45 Ibid., 165 .

46 Judith Pollmann, 'Of living legends and authentic tales. How to get remembered in early modern Europe', Transactions of the Royal Historical Society, 6th series 23 (forthcoming 2013).
} 
contextualise the local narratives with historical data they derived from respected and well-known historians, with archival material (Soeteboom) and by naming many eye witnesses (Van Duin). Thus they compensate for the loss of external data during the process of smoothing and flattening typical of oral transmission. Still, a good plot remains essential for the longevity of tales. And such a plot had to meet certain moral standards if it was to survive in the ages to come. It is typical that the only story from Waterland that found its way into the developing national histories of the eighteenth and nineteenth centuries was the story of Meindert Leendertsz, the God-fearing son who saved his mother from the Spanish soldiers. He was remembered with a new monument, a painting, poems for children, a theatre play and novels in the nineteenth century. ${ }^{47}$ With the rise of nationalism, civic virtues and devout self-sacrifice for the nation were elaborated in an elevated style. However, such heroes were quite rare in real life. The war on the ground was harsh, and its heroes were valiant but not very sentimental. The locals had their own tales of the revolt. Most of their heroes, like Van der Lee, De Guyon or the freebooters from Zaandam, did not yet meet the standards of romantic heroism: selfsacrifice was far from their guiding motive. On the contrary, they succeeded through cunning tricks and brute force: in order to survive they answered violence with more violence and did not hesitate to maltreat the enemy-even when the enemy consisted of the inhabitants of a neighbouring village. In a cruel war, cruelty was a legitimate weapon. Their descendants apparently admired their bravery and liked these stories. But in order to preserve them for the future, they had to be accommodated to a new and different historical context and adapted to changing needs and norms.

47 See e.g. Adriaan Eck, De nieuwe gedenksteen voor Lambert Melisz., bij gelegenheid der Bossu-feesten onthuld te Hoorn, den 14 October 1873 (Hoorn: Persijn, 1873), 324-334, 367-377; Anna Petronella Muller-Westerman, Lambert Melisz, of De ouderlievende jongeling van Westzanen. Vaderlandsch tooneelspel, in drie bedrijven (Amsterdam: Westerman en Van Hulst, 1834). 


\section{APPENDIX \\ CY SUIVANT A LA CHANSON PROMISE ET MENTIONNÉE EN L'EPISTRE DEDICATOIRE}

\section{CHANSON}

faite l'an 1566 par un paysan des environs le Pesquencour sur le sujet de la deffaite des brise Images à Marchiennes le 25 d' Aoust dudit an par le sieur de Guyon

Les huguenots sont assemblez

Pour les images ruiner

Et sans respecter le dimanche

Ils sont venus droit à Marchenne.

Ils ont abbatu les autels

En haine de l' Église saincte

Quand ce fut le Lundy matin

Ils ont trouvé des Catholiques.

Fery Guyon premier nommé

Le grand bailly de Pesguencour

Et nombre de ses Hennuyers

A l' Église a donné secours.

Ils y marcherent vaillament

Aux huguenots donnant l'allarme

Es maretz de monsieur l'abbé

Ils leurs ont là livré bataille.

En nombre de dix à douze vingt

Sont demeurez dessus la place

Et le Lundy au desieuner

Les huguenots avoient conclu

D'estre au disner à Bouvenies

Pour les images ruer jus

Mais ils n'avoient pas bien conclu

De prendre en ce lieu leur disner.

Ils estoient desgoustez de chair

On les voit pescher aux anguilles

Et le Lundy apres disner

Y revint tout nouvelles gens.

En despitant les Catholiques

Et aussi le saint sacrement

Ils n'y furent pas longuement

Pensant retourner tous ensembles. 
Car estans au gist à Brillon

Sont endormis dedans les kemmes

Les huguenots de Valenciennes

Quand ils en ont ouy le vent.

Ont envoyé poste sur poste

S' en enquestans par le pays

Quand ils ont sceu la verité

Ils en ont bien gratté leurs testes.

Les freres en Christ sont mis à mort

Jamais plus n'iront a la presche

Celui qui fit cette chanson

A bien gaigne les gris palto

Et voudrait bien gaigner sa vie

A combattre les Huguenots

Príons la Sainte Trinité

Qu'elle nous soit tousiours propice.

FIN 